\title{
IN THE SAME SERIES
}

How to Study a Novel John Peck

How to Study a Shakespeare Play John Peck and Martin Coyle How to Begin Studying English Literature Nicholas Marsh

How to Study a Jane Austen Novel Vivien Jones

How to Study a Thomas Hardy Novel John Peck

How to Study a D. H. Lawrence Novel Nigel Messenger

How to Study a Charles Dickens Novel Keith Selby

How to Study a Joseph Conrad Novel Brian Spittles

How to Study a Renaissance Play Chris Coles

How to Study Modern Drama Kenneth Pickering

How to Study a Poet John Peck

How to Study Chaucer Robert Pope

How to Study Romantic Poetry Paul OFlinn

How to Study an E. M. Forster Novel Nigel Messenger

How to Study Modern Poetry Tony Curtis

How to Study Milton David Kearns 


\section{HOW TO STUDY LITERATURE}

General Editors: John Peck and Martin Coyle

LITERARY TERMS AND CRITICISM

New Edition 


\title{
LITERARY TERMS AND CRITICISM
}

\author{
New Edition
}

\author{
John Peck \\ and \\ Martin Coyle
}


CC John Peck and Martin Coyle 1984, 1993

All rights reserved. No reproduction, copy or transmission of this publication may be made without written permission.

No paragraph of this publication may be reproduced, copied or transmitted save with written permission or in accordance with the provisions of the Copyright, Designs and Patents Act 1988, or under the terms of any licence permitting limited copying issued by the Copyright Licensing Agency, 90 Tottenham Court Road, London W1P 9HE.

Any person who does any unauthorised act in relation to this publication may be liable to criminal prosecution and civil claims for damages.

First edition 1984

Reprinted 1985, 1986, 1987, 1988, 1989, 1990, 1991

Second edition 1993

Published by

THE MACMILLAN PRESS LTD

Houndmills, Basingstoke, Hampshire RG21 2XS

and London

Companies and representatives

throughout the world

ISBN 978-0-333-58887-1

ISBN 978-1-349-13155-6 (eBook)

DOI 10.1007/978-1-349-13155-6

A catalogue record for this book is available from the British Library 


\section{Contents}

1 English, American and post-colonial literature: a brief survey

2 Poetry

3 Drama

4 The novel

5 Critical concepts

6 Critical positions and perspectives

Further reading

Author index

213

Subject index 
For Rachel and Pamela 


\section{$\overline{\text { General editors' preface }}$}

EVERYBODY who studies literature, either for an examination or simply for pleasure, experiences the same problem: how to understand and respond to the text. As every student of literature knows, it is perfectly possible to read a book over and over again and yet still feel baffled and at a loss as to what to say about it. One answer to this problem, of course, is to accept someone else's view of the text, but how much more rewarding it would be if you could work out your own critical response to any book you choose or are required to study.

The aim of this series is to help you develop your critical skills by offering practical advice about how to read, understand and analyse literature. Each volume provides you with a clear method of study so that you can see how to set about tackling texts on your own. While the authors of each volume approach the problem in a different way, every book in the series attempts to provide you with some broad ideas about the kind of texts you are likely to be studying and some broad ideas about how to think about literature; each volume then shows you how to apply these ideas in a way which should help you construct your own analysis and interpretation. Unlike most critical books, therefore, the books in this series do not simply convey someone else's thinking about a text, but encourage you and show you how to think about a text for yourself.

Each book is written with an awareness that you are likely to be preparing for an examination, and therefore practical advice is given not only on how to understand and analyse literature, but also on how to organise a written response. Our hope is that although these books are intended to serve a practical purpose, they may also enrich your enjoyment of literature by making you a more confident reader, alert to the interest and pleasure to be derived from literary texts. 


\section{How to use this guide}

Literary Terms and Criticism is a practical guide to the study of English literature. This revised edition includes a number of new topics and new areas, such as twentieth-century poetry and women's poetry, as well as a number of additional critical terms, such as 'Ideology' and 'Carnival'. Section 6, dealing with critical theory, has been revised to include recent developments in criticism, and we have also now included a section on further reading. Our main intention, however, remains that of offering practical advice on how to come to grips with the texts and authors you are studying.

The guide itself is basically a dictionary of literary terms. It resembles other such dictionaries in that it attempts to provide essential information on a wide range of literary topics. It differs from other dictionaries, however, in that we have tried to produce a book that meets the particular needs of students at school, college and university. This means that the overall structure of the book, the range and kind of terms included, and the approach adopted within the individual entries, are somewhat unorthodox as compared to other guides to literary terms.

First, the overall structure: the standard approach is to provide a straightforward alphabetical listing of terms. This should make things easy to find, but a list of terms is not all that helpful if you are not entirely sure what you are looking for. We have, therefore, divided the book into six sections - a 'survey of literature', 'Poetry', 'Drama', 'The novel', 'Critical concepts', 'Critical positions and perspectives'. If, for example, you are studying a novel, you might find a number of useful ideas simply by browsing through the Novel section. If you know exactly what you are looking for, the quickest way of finding the relevant entry is to consult the Subject index at the back of the book. Our own experience as students was that we were not only puzzled by specific terms, such as 'metaphysical poetry', but also lacked broader ideas about literature. 
The Poetry, Drama and Novel sections, therefore, begin with introductory essays that might help you understand the characteristics of the major genres.

These introductory essays, along with the survey and the introductory essay on criticism in the final section, are intended to provide a sense of the broad picture. They are followed by more specific entries, alphabetically arranged. We should point out that this is not an all-inclusive guide: we do not include terms such as 'limerick' which are not in any way central to the academic study of literature. The exclusion of minor terms has allowed us room to include period terms such as 'Renaissance poetry' and 'the eighteenth-century novel'. These are not, strictly speaking, literary terms, but they are descriptive terms that students encounter. It seemed more important to cover the terms and ideas you are likely to meet, even to the extent of including a separate entry on Shakespeare, than to worry too much about maintaining a pure approach. The intention is to provide helpful information which is directly relevant to your studies.

This idea was also uppermost in our minds in determining the approach adopted within each entry. We do not attempt to cover the entire history of any term, nor do we attempt to list all the authors who have chosen to work in a certain mode. In their place we have substituted critical discussion, attempting to provide guidelines for your study of literature. Underlying many of the definitions is the idea that literature attempts to come to terms with, or order, the complexity, or disorder, of experience. You may find this idea limiting, but it should prove useful in helping you to find your critical feet. Our hope is that the definitions will show you how to get started, but really this is a guide to grow out of as you become more confident and learn how to develop and express your own ideas about literature.

Probably the best way to use this book is to browse through it, stopping at whatever catches your attention. But, as we have said, there is a Subject index which should enable you to find a specific term quickly. In addition there is an Author index. Most of the major authors in English are discussed in the guide: by following up the entries in the Author index you should discover some quite useful guidelines about how to approach and discuss an individual author. The major shortcoming of most guides to literary terms is that they so often fail to tell you what you want to know; our hope is that we have gone at least some way towards providing the kind 
of basic information and critical discussion that you are likely to find useful.

In preparing this new edition of Literary Terms and Criticism we have particularly focused our attention on expanding sections 5 and 6 which deal with 'Critical concepts' and 'Critical positions and perspectives'. What we have sought to do is to include as many of the new terms and critical ideas of post-structuralism, feminism, Marxism, New Historicism and modern psychoanalytic criticism as we feel are useful and accessible to students embarking on the serious study of literature. We are conscious of the difficulty of some of this new material but also of its importance to students. Very often you will find that an idea discussed in section 5 , under critical concepts, is discussed further in section 6 , the critical positions section. The two sections are intended to be complementary and to raise more complex ideas than in the preceding sections of the guide.

We should like to thank those who have helped us in the preparation of this revised edition. In particular, we are grateful to our colleagues Catherine Belsey, who discussed some of the new material with us, and Fred Botting for his comments and ideas. We are also grateful to Cathryn Tanner at Macmillan for offering us the opportunity to prepare this new edition.

University of Wales, Cardiff 